\title{
INTRODUCTION: END-OF-TERM ANXIETIES AND IMPROVISATION
}

\author{
Grant Amyot and Luca Verzichelli
}

Any observer of the Italian political situation will likely agree that 2005 was yet another transition year, dominated by mostly predictable facts and events. However, a series of factors reveals the imponderable, and somewhat fortuitous, nature of political change in Italy during a period certainly pervaded by the expectation of impending events but also not altogether lacking in critical situations and noteworthy occurrences.

On the side of "predictable" events, there are many circumstances to note. A positive result for the center-left in the regional elections of 2005, for example, was on the whole easy to forecast, as was the further decline in popularity of Silvio Berlusconi, due to a less than impeccable performance in government and to choices that owed more to nearsighted calculations of political advantage than to clear policy objectives. In addition, the fierce antagonism between the center-left and center-right coalitions did not help to reduce the persistent elements of friction within each of them. It was thus easy to foresee the slow progress through an uncertain political agenda, with a tendency to constantly renegotiate some crucial choices and to postpone others. Yet again, therefore, the provisional quality of a long transition was apparent, and any secure anchorage still seems out of reach.

These opening thoughts suggest a cyclical interpretation of political change: exactly as had occurred in 2000, the final year of this legislature showed that attention had shifted back to the dynamics of

Notes for this section begin on page 45 . 
domestic politics and evinced increasing signs of difficulty for the government and its majority. These difficulties climaxed with a resounding defeat in the round of regional elections that took place only one year before the end of the legislature. As in 2000, these electoral losses ushered in a formal government crisis, which was quickly resolved by the majority but without overcoming all of its internal differences over both leadership and policies. However, again as in 2000, the new government was able to bring some of its policy initiatives to fruition, among them a revision of the Constitution- $\mathrm{a}$ far more profound modification than that of constitutional law no. $1 / 2001^{1}$ - which was subject to a confirmatory referendum to be held in the course of the following "electoral year."

Even some of the "hottest" issues brought back onto the political agenda in 2005 show a parallel with 2000. For example, the action taken in the areas of school and university reform and the proposals for the reform of retirement bonuses (trattamento di fine rapporto, or TFR) have touched questions that the Ulivo governments had already addressed during the final phase of the 13th legislature. ${ }^{2}$

However, we can also emphasize a few unpredictable factors, or at least the "disconnected" nature of many of the events that occurred this year. The political agenda was often characterized by variations in rhythm and by changes in direction that some political actors were forced to make. Some real surprises have emerged. For example, the bizarre pace of the parliamentary timetable suffered from constraints placed on it by the political debate (in particular, the long verifica, or reckoning, within the majority that preceded the government crisis in April and that in one way or another lasted at least until September). It was then reorganized to further the objectives of a coalition that was once again united, at least around the "package" of reforms approved in the final months of the year.

A particular instance of disconnection and chaos was the process leading to the reform of the electoral system (law no. 270 of 14 December 2005), which, after months of legislative inactivity, was suddenly set in motion again following the governmental crisis. The system that emerged must be considered "highly proportional," since the thresholds of exclusion-in particular, those for parties within coalitions-are not a strong deterrent against the fragmentation of the party spectrum. If it is still technically classifiable as a "mixed" system, therefore, it is only so in the sense that it combines with the principle of pure proportionality the majority premium, an Italian invention practically unknown on the democratic planet. This and the other innovation, whereby the parties that plan to vie for the majority premium must formulate a common platform and present a leader of the coalition 
as candidate for premier, should constitute a complicated mechanism combining a typically "consensual" rule for allocating seats with the majoritarian and bipolar legacy of recent years. The word "should" is apt here, because the way that the majority premium functions in the two chambers (in the Chamber of Deputies it is assigned on a national basis; in the Senate, on a regional one) could, according to authoritative forecasts, ${ }^{3}$ produce different results in the two houses and the risk of a governmental stalemate caused by a not improbable "draw" in the upper chamber.

In addition, although the premier was able to convince all the members of Parliament in his own majority to turn the electoral system upside down with the intent of guaranteeing himself the greatest possible advantage in 2006 (this by exploiting the fragmentation of the opposition coalition and the better results obtained by his party and more generally for the Casa delle Libertà in the proportional vote), in the last months of the legislature he was not able to achieve other reforms. For example, the amendment of the par condicio for electoral campaigns $^{4}$ had the same purpose but was not supported by all the coalition parties, in particular, by the Union of Christian Democrats and Center Democrats (UDC).

This picture strengthens the impression of a nervous, often confused timing of Italian political events. The year 2005 was therefore a classic pre-electoral year but also a period of great effervescence, due to some by now fairly familiar factors (including the particular manner and tone of Berlusconi's leadership) but also some new, explosive elements. For example, the investigations of the bank takeovers in effect monopolized the attention of the media for the entire second semester. A few of the events in question are already ripe for detailed interpretation and have thus been treated extensively in this edition of Italian Politics. For other matters, such as the proportional electoral reform, which will not be implemented until April 2006, it will be advisable to wait for further developments.

However, an analysis as events unfolded at the end of 2005 can help to capture the direction of change of a political system that, although in a fairly uncertain context, continues to evolve. In particular, after reflecting on the events of 2005, we believe we should focus our attention on three elements. In the first place, we will track the evolution of the parties, still absorbed in discussions on how they are to coalesce, choose leaders, and formulate common programs in spite of the substantial stability of the electoral groupings and, especially, the fact that we are seeing a return match of the same electoral duel as 10 years ago. In the second place, the enactment of public policy in the principal sectors has revealed in too many cases an uncertain 
and illogical process of decision-making, giving the impression of a reduced ability to solve problems and of changes being limited to the form and the instruments of policy without producing significant and lasting results in "social learning." The resulting risk is all the more dangerous because it seems likely, in many decision-making areas, to survive the alternation in government between leaders and blocs. In the third place, it is useful to look at the evolution of the relation between politics and society, which in the course of 2005 has shown several moments of tension and the return of the risk of a bifurcation between the two spheres, due to the declining public perception of an ethical sense in governmental institutions and, more generally, in politics.

\section{Leadership and Strategies in the Two Coalitions: Predictable Outcomes, Difficult Preparation}

In 2005, the debates over the leadership within the two poles developed in fairly different ways but along inevitably parallel tracks. The events discussed in the chapter by David Hine and Chris Hanretty-the government crisis and the long battle between Silvio Berlusconi and Marco Follini, which led in autumn to the latter's resignation as secretary of the UDC-constitute the principal stages in the transformation of the center-right coalition. In view of the upcoming 2006 election, the result was in the end a foregone conclusion (Forza Italia's pre-eminence and therefore Berlusconi's expectation of again running for the premiership). However, Berlusconi's path has seemed more difficult than expected, and the strategy chosen at the end of a very hot summer-electoral reform in a proportional direction, strongly urged by the UDC, which re-establishes the parties' autonomy and the logic of internal competition expressed by the soccer metaphor of the "trident" made up of the leaders of the major parties in the coalition-raised the price of cohesion, with Berlusconi himself as well as his party suffering the consequences. The episode of the choice of a candidate (although at year-end there were three) to stand against Walter Veltroni in Rome's 2006 mayoral election is an example of this.

Did this signify an erosion of Berlusconi's leadership, or was it a problem of achieving actual unity around a center-right platform? The defeat and resignation of Follini appear to have slowed (or frozen) the former. The price paid by Berlusconi, as suggested above, has nevertheless allowed him to enter the fray very early and on his preferred ground-in a campaign centered on a personal party and (so long as it is possible) on television presence. On the other hand, the National Alliance (AN) and the UDC of the resurrected (in terms 
of party politics) Pierferdinando Casini have persisted in refusing any concessions to Forza Italia (FI). They have not supported it, for example, on the reform of the par condicio, on the correction of the financial maneuver, and on the ex-Cirielli law, which without the UDC's veto would probably have included clauses that were more helpful to the ex-minister of defense, Cesare Previti, in his trial. This episode constituted a rare example of a failure to approve one of the provisions ad personam inspired by Forza Italia, demonstrating that the approach of the appointment with the voters strengthened the UDC, making it less compliant to the demands of the premier. But other events during the year also showed that Berlusconi's personal appeal as a unifier, the "catalyst" of a moderate consensus, was fading. The criticisms he received on several occasions, even from center-right commentators, the polemics surrounding his all too prudent conduct in the handling of the Fazio case, and finally the heated discussion with Vittorio Feltri in the course of an episode of Porta a Porta in mid-December are all evidence of his diminishing appeal. But there have also been problems with the solidity of the coalition, with some, even if limited, cases of "desertion" of the parliamentary groups of the majority and the defection of a part of the Nuovo PSI, which merged into the center-left.

On the other hand, Berlusconi was able to respond to the attacks, thanks to a relative harmony with the other partners. Gianfranco Fini's party is still in the final analysis a faithful ally, as its loyalty to the author of its political legitimation, or sdoganamento, remains firm. There is still a strong rapport with the Northern League, based on shared views on many issues, ranging from Europe to taxes.

During 2005 we saw the re-emergence on several occasions of the crucial problem of the divergent interests and social groups represented by the majority parties, precisely the problem that makes Berlusconi's unifying role essential. The different geographical distribution of moderate voters-those of AN and the UDC in the South, those of the League and a significant part of FI in the North-has caused inevitable conflicts on a wide range of questions, primarily pension reform and economic measures. The idea of a single party of moderates, again proposed by Berlusconi after the regional elections and yet again early in November, has not accidentally been put to one side in favor of a more consensual solution centered on the return to electoral competition in a proportional framework.

Aside from the faded image of the leader and the imperfect unity of the coalition, the problem faced by the center-right is that of holding together a consensus of moderate opinion on the local level. This is difficult for a party like Forza Italia, which lacks a grassroots organization. In this respect, one of the main novelties of the year was the show 
of strength in Sicily of Raffaele Lombardo's Movement for Autonomy, which gained its initial success within the coalition in the city council election in Catania but then (in the November-December election round) created the conditions for a dramatic defeat of the center-right candidate in Messina, first by selecting a candidate of its own to run against him and then by not supporting him in the second round.

On the other side of the political spectrum, we have Romano Prodi and his long-standing effort to build a finally united, but also sufficiently reliable, center-left coalition. The narrative of events reconstructed by Jonathan Hopkin in his chapter shows how difficult this undertaking was in the course of the last year of the legislature. Just as Sisyphus must endeavor time and again to push a boulder up the slope that inevitably sends it back down again, so Prodi found in the course of 2005 that he had to repeatedly retrace a path of coalitionbuilding by now familiar to him and to the supporters of the Ulivo scattered among the Margherita and the Left Democrats (DS). The year opened with Prodi's official return to Italian politics and continued with a series of voyages: that of ideas and proposals begun in the "Factory"; the actual road trip (this time on an 18-wheeler) that preceded the primaries; and also a difficult political voyage among the many strategic solutions (and snares) offered by the new electoral system, with the additional problem of Prodi's personal position as a candidate. The difficulties for the center-left do not mirror those of the center-right in the sense that here it was primarily a question of reconciling the demands of different political groups and actors, without the sharp conflicts among electoral, social, and local interests and constituencies felt by the Casa delle Libertà. It is no surprise, however, that unity remained a difficult goal for the center-left as well, and that paradoxically the prospect of victory in 2006 in some measure served to weaken the thrust toward unity.

In any case, other specific factors also contributed to the self-defeating behavior of the center-left: the different histories of the parties that compose the center-left Unione have generated inferiority complexes in some and mutual suspicions in others. The DS are not only the largest party in the coalition, but also the only one with a relatively strong structure, raising concerns among the other actors that it might hegemonize the alliance. And in the background there are also important programmatic differences to be resolved, such as how far the radical left can share the reformist vision-inspired in part by the Blair experience-which is favored by the leaders of the two core parties. The polemics about which center-right laws to abrogate have been an index of these tensions. The reformist wing did not ultimately disagree, for example, with some of the motivations for the Biagi law or 
Berlusconi's pension reform; rather, it considered it an advantage to find them already approved, in order to avoid conflicts within its own coalition. On the other hand, abrogating the Biagi law was a major plank of Communist Refoundation's program. Even the question of withdrawing Italian forces from Iraq, for example, required difficult negotiations on the left. ${ }^{5}$ Differences about policy later took second place to polemics on the composition of the lists of candidates and on the allocation of resources for the election campaign, but they could obviously regain significance in the future.

Next to the changed prospects for the supporters of the Ulivo, or Democratic Party-a concept back in vogue in 2005-the other factor emerging from a rereading of the evolution of the center-left during the year is the unpredictability of the public's reactions. We are not referring here so much to the electorate's behavior at the polls, although it, too, has been the subject of somewhat inaccurate projections, as Salvatore Vassallo points out in his chapter, but rather to how activists and sympathizers of the Unione have interpreted political events and how they have reacted to them. There is no doubt that beyond any possible celebration and exploitation of this political event, the impact of the primaries held by the Unione in October, in terms of overall participation and relegitimation of Prodi's personal leadership, was strong, as was pointed out even by some members of the opposing coalition. The outcome of the 4 December primaries to choose the Unione's candidate for the presidency of the region of Sicily was also significant, with over 180,000 going to the polls and approximately 65 percent of the votes being cast for Rita Borsellino, clearly showing she garnered support well beyond the electoral bases of the parties backing her.

But the most surprising result, in this year of primaries, was surely the double personal success (including of course the April election results) of Nichi Vendola in Puglia. In this case, besides the inherently politically relevant fact-the credit extended by voters to a representative of Communist Refoundation-there was in addition the strong sign of discontinuity represented by the successful candidacy, in such a difficult competition, of a politician like Vendola, who is openly gay, a poet, and a supporter of the anti-Mafia movements that are often in open confrontation with the establishment. Vendola first won over the majority of the supporters of the Unione and then also garnered widespread support among centrist voters in Puglia, bolstered by his pride in being "different" but also by knowing how to avoid gratuitous conflict with the traditional and religious values of the region. On the terrain of religious values, in fact, the center-left-or rather, its left wing-has not known how to read the public's attitude and foresee 
its reactions. As Chiara Martini notes in her chapter, the center-left misread the public mood not so much on the question of artificial insemination itself as on the possibility of using the tool of the referendum for such complex issues, thus gratuitously creating a new reason for disunity in the coalition. Perhaps this too can be listed as a factor that was in some ways predictable; nevertheless, its effect was also conditioned by improvisation and nervousness.

\section{The Decision-Making Process: Uncertainty of the Political Agenda and Half-Reforms}

In recent years, the tendency for many public policies to depend on the electoral cycle of a given majority has become an established fact, thereby signaling a break with the traditionally consensual nature of Italian policy-making while overcoming the inertia that has always characterized decision-making in some sectors. At the same time, these policies seem to undergo a tortuous formulation and an uncertain implementation because of the conflictual nature of the government coalitions and the often difficult relations with the other forces on the policy scene. Commenting on the results of the government's activity in 2004, Carlo Guarnieri and James L. Newell noted the uncertainty of some legislative initiatives and the prices paid by decision-makers in the "laborious processes of negotiation within the coalition."

The year 2005 certainly has not reversed the trend. On the contrary, some reasons for conflict seem to loom larger, in some cases because of the emergence of new constraints that restrict the win set of solutions available to decision-makers. On the other hand, the government's "decisionist" style and its capacity to impose fast-track timetables and exercise a certain partisan control over parliamentary votes now constitute the rule rather than the exception. Government actually moves forward, as the six-by-six-meter posters put up at the end of the year by Berlusconi's new pre-electoral campaign claimed. The battle of the posters was then transferred to brochures, brandished by the premier and his ministers to boast of alleged record-breaking effectiveness and political results. But what does all this mean in terms of real policy change?

The answer to this question must take into account the fact that many public policies are often considered "in place" when legislative action has remained at the level of pure retooling. Or in many cases, policy change boils down to decisions of limited impact that represent minimal costs for the parties and members of Parliament when compared to the media benefits of a trumpeted achievement. Or again, 
sometimes it is a question of policies that are destined to receive very limited implementation - or indeed, no implementation at all. Therefore, many decisions, even of substantial legislative importance, may be made "so that nothing changes," or they end up having very little effect in terms of policy output. From this point of view, the year in question also shows an evident gap between "legislative results" and actual "reform." For example, there has been a growing alarm over the economy's loss of competitiveness, a concern voiced by many representatives of the business world, starting with the president of Confindustria, Luca Cordero di Montezemolo.

The decree and the government bill presented in March, analyzed by Grant Amyot and Francesco Marangoni in their chapter, in addition to the Economic and Financial Planning Document (DPEF) of July and the subsequent chaotic maneuver in the fall, introduced a wide range of individual measures to support business, along with some legislative and tax adjustments. However, given the scope of the problems, they have seemed relatively inadequate. For example, one question raised by many economists and by the Organisation for Economic Co-operation and Development (OECD) in its last report has not been addressed ${ }^{7}$-that of the lack of competition in many services and professions, which leads to greater costs for Italian exporters. In spite of frequent free-marketeering statements, the premier and his coalition have not wanted, especially in a pre-electoral year, to make enemies of important constituencies of voters. Other structural problems, such as the sectoral concentration of exports, have not been addressed at all.

Budgetary policy, proceeding by improvisation and in fits and starts, has also been affected by the general political instability. Even in a context of substantial continuity in policy aims, individual decisions have been affected by persistent institutional turbulence (the government crisis in April, the resignation of the economy and finance minister in September while the budget bill was being drafted, and the subsequent conflict between Tremonti and Fazio), as well as the "stop-and-go" effect of Italy's delicate situation of being under "special observation" in the context of the Economic and Monetary Union (see Vincent Della Sala's chapter in this volume). Within this framework of constraints, the passage of the last budgetary maneuver of the legislature became, inevitably, the focus of strong pressure on the part of the members of the coalition. The UDC, with the support of AN, persistently pressed to insert a number of measures to support families, from bonuses for newborns and adopted children to deductions for daycare fees. In the end, Casini's party in large measure won its battle, whereas AN and the Northern League were less successful with theirs. ${ }^{8}$ To handle the many demands while working within the 
framework imposed by the European Stability Pact, the government had to introduce a maxi-amendment to the budget bill, protecting its own proposals from attack by invoking the confidence mechanism. The coalition parties finally dropped some demands after the premier's promise of a new financial decree (the so-called mille-proroghe, or "thousand extensions," decree), which was presented at the end of the budget session. In sum, this does not appear to be a rigorous way of managing public finances or an approach that could provide a concrete response to the serious problems of the country, although we must not forget some useful measures introduced by Tremonti-for example, the reduction of employers' social insurance contributions.

Another crucial turning point during the year was the reform of the TFR, which was finally passed in December. For the first time, workers have the choice of directing contributions destined for the TFR to investment funds or other financial vehicles. The reform, which gives preference to closed investment funds established by union agreements, met with resistance on the part of the insurance companies. Taking advantage of other pressures as well, they secured a postponement of the implementation of the law until 2008, a fact that qualifies as yet another element of uncertainty and improvisation, even in the context of a "done deal." A similar point should be made about the law "for the protection of savings"-rewritten and adopted immediately after the resignation of the governor of the Bank of Italy, Antonio Fazio-which has the appearance of a half-reform or one with a deferred implementation, due in this case to the interplay of the various political forces and lobbies. Indeed, this law, in the rush for "fast-track" adoption by the executive, contained only a few of the measures that had been proposed to aid investors while lightening some penalties for fraudulent accounting.

In the school sector, the reform introduced by Minister of Education Letizia Moratti does not clearly address the problem of the quality of education and, as Giancarlo Gasperoni explains in his chapter, poses implementation problems, stemming in part from the regions' role in creating new vocational courses of study. To remind us that the problems of the Italian educational system remain largely unresolved, a year-end OECD report showed that Italy still lags far behind in the secondary education rankings, including students' knowledge of mathematics and science, in spite of the high costs of the educational system. ${ }^{9}$ With respect to universities, the free-market ideas often invoked by the premier have in reality not been followed up in the formulation and implementation of policies: there is almost no trace in the law reforming the career structure for professors of any moves toward market discipline and greater competition in the 
sector, comparable to those introduced in Great Britain under Margaret Thatcher and later under Tony Blair.

The intensified focus on domestic politics did not cause the government to scale back its ambitions and involvement in European and international politics, but its interventions there have also run into various difficulties and led to some partial failures. On the European front, there has been an attempt to gain room for maneuver within the Stability Pact, exploiting the problems encountered by countries like France and Germany. The revision of the pact, however, was less favorable to Italy than the government had hoped, since it set the level of public debt as the basic criterion in the process of multilateral surveillance. As Vincent Della Sala explains, Italy's high debt, together with the behavior of some representatives of the Berlusconi government, who have criticized the pact and attempted to blame the euro for the ills of the economy, has weakened the Italian position. On this issue, the clear differences in the degree of "Europeanism" within the majority have resurfaced, and its distance from those influential forces (among them big industry and high finance) that have long been convinced that there is no alternative to Europe has been made clear.

On the international front, while the bipolar division between the majority's support of the US action in Iraq and the center-left opposition's determination to "exit" from the Iraqi situation persisted in 2005 (although each position is expressed in a wide variety of ways within each camp), there was perhaps a novelty of some importance to the overall picture of foreign policy behind the events discussed by Marco Clementi. The Sgrena-Calipari case shows how new constraints on Italy's policy emerged from the crisis following the calamitous operation near the Baghdad airport on 4 March 2005, but it also shows how the government tried to adopt a new profile in the uncomfortable postinvasion Iraqi situation. Perhaps new spaces are being created for the bipartisan handling of at least some aspects of the fight against terrorism. And the same outcome can be expected in future for the Italian position on the reform of the United Nations, developed in the course of the year under the cautious management of the minister of foreign affairs, Gianfranco Fini.

But the issue about which the government (and in general the political system) has been most indecisive and incapable of finding solutions is the episode of the bank takeovers. This was connected, in a forced and certainly not very effective way, to the goals of the proposed law on savings. In his chapter, Marcello Messori details the events set in motion by the bids of ABN AMRO (for the Banca Antonveneta) and of the Banca Bilbao Viscaya (for the Banca Nazionale del Lavoro) and the subsequent emergence of a depressing reality of clientelistic relations 
and low ethical standards in public institutions. From a purely political standpoint, the relevant factors are the support that the leadership of the Bank of Italy has had among elements of the majority-especially, but not only, from the Northern League-and the attempt, long pursued by Berlusconi himself, to justify and sustain a strenuous defense of the "Italianness" of the banks that was clearly in conflict with the country's political position and its responsibilities within the EU. In an echo of these maneuvers, the leaders of the DS “rooted” for Unipol's takeover of the Banca Nazionale del Lavoro, as was revealed by telephone wiretaps heard by the investigating magistrates.

Overall, the government's policies in 2005 betrayed a growing sensitivity to the timetable of domestic politics-shown in particular by electoral preoccupations-and a greater willingness to submit to a multitude of contradictory pressures by lobbies and social forces, without, in some cases, a clear vision of the objective to be pursued. In addition, many policies have remained in an amorphous state. The budgetary maneuvers and the reforms of the educational system, as well as other events only touched upon in this volume's chapters, were indicative of a chaotic and disconnected process of piecing together. Moreover, behind the late and incomplete initiatives there lurked a dangerous drift: the "syndrome of program completion," which leads the chiefs of the executive to make choices often dictated by contingent interests, sometimes in conflict with each other, and to push the envelope with procedural manipulations, such as constant tinkering with the parliamentary agenda and frequent recourse to motions of confidence. ${ }^{10}$

However provisional, the answer to the question whether the events of 2005 represent a reshaping of policy-making in Italy must ultimately be no. The decisions made were at best defensive (as the episode of the reform of the Stability and Growth Pact shows) and reactive. They were almost never timed carefully and almost always required rethinking. The "end-of-season sales" dynamic that characterized the decision-making process in the second semester of 2005 was sharpened by a government-opposition relationship that was certainly not inspired by the concept of fair play; it affected many important matters and produced a plethora of formal results that, however, almost never provided a definitive solution to the problem at hand. Obviously, evaluating whether the glass of effective decision-making is more or less empty, compared to the inability of the system, from the administration to the media, to put the government's choices into practice, is a politically sensitive subject that must be left to Italian opinion-makers (and especially to the voters). Indeed, the new media offensive launched by Berlusconi in fall 2005 with the poster 
campaign, followed by the self-satisfied tenor of his year-end press conference (which inaugurated an innumerable string of appearances on television and public statements by the premier), was precisely an attempt to convince Italians of the decisiveness of the government's proposals despite pre-existing constraints, the "self-destructive" pessimism of the left, and, "naturally," the hostility of the media toward Berlusconi himself and his party.

\section{The Political System and the National "System": Growing Disquiet}

We said at the outset that although 2005 was certainly a transitional year for Italian politics, it did demonstrate the limits of the "new" bipolar system, limits that undoubtedly have an effect on the relationship between public opinion and political institutions. The data marshaled at the end of the year by Ilvo Diamanti are incontrovertible: ${ }^{11}$ Italian society is permeated by constant anxieties to which the political system seems slow to respond. The year opened with an event-the railway disaster of Crevalcore-which, although due to human error, reminded the country of the poor quality of its public services (and of the resulting lack of security). Fatally, the end of the year was also darkened by the train collision at Roccasecca, less serious in its consequences but equally liable to prompt negative reactions and critical judgments of the authorities. The transportation sector, indeed, is an unforgiving test case of the actual "modernity" of a country like Italy. It is the "little" events that speak here, from newspaper reports on the plight of commuters in many Northern cities to the reiterated complaints about the execrable sanitary conditions on public transport to the problems immediately produced by the-widely forecast-snowfalls in February and December on the Salerno-Reggio Calabria or the Roma-L'Aquila highways. On a question linked to new infrastructure, a heated polemic emerged toward the end of the year between the citizens of the Val di Susa and the supporters of the European high-speed train project (including the government but also the leaders of many center-left local authorities): the Italian end of the Turin-Lyons line would traverse the area.

Polls show that the Italian public is apprehensive about market reactions and news of economic stagnation and the competitiveness gap: it perceives the extent of the difficulties faced by the politicians in addressing such issues (see on this the chapter by Grant Amyot and Francesco Marangoni). In 2005, consumption grew by barely 1 percent, ${ }^{12}$ a sign of uncertainty about the future of the economy that probably has also affected voters' behavior and priorities. In a society that 
at times seeks to anticipate political action, there have been several clear signs of unease. The peripheries are more "active" at such times, and not only on purely local questions, such as the protest against the high-speed train route. The events of 2005 showed the many faces of a single problem that can be summed up as the total absence of the state, evident at Scampia, in Locri, in the repeated discoveries of cases of corrupt administration (in particular, in the health-care sector), but also, by contrast, in demonstrations of courageous "de-alignment." Particularly striking was the protest by students in the Locri area, with their cry of "kill us all" directed against criminality but implicitly also against representatives of the institutions and the older generations.

Conflicts between the "state" in the wider sense and a segment of society also emerged in Bologna, where the strong line taken by the center-left mayor, Sergio Cofferati, in evacuating some immigrants' illegal encampments sparked protests and led to scuffles between demonstrators and the police in front of Palazzo Accursio, the city hall. A comparison with the very different situation in the French banlieues, where acts of criminality and vandalism proliferated in 2005, is obviously untenable. However, given the more recent and limited character of immigration in Italy with respect to France, one cannot help but consider the events in Bologna as the precursor of possible (but not inevitable) further developments. ${ }^{13}$

In the intricate knot of delicate relations between politics and society, two other strands are entwined: the long-standing secular-Catholic battle and the more recent conflict over the autonomy of science with respect to sensitive ethical issues. The death of Pope John Paul II in April cast an immense media glare on expressions of renewed and intense religious feeling (with the cry for immediate sainthood, "Santo subito," raised among the crowd at St. Peter's) that did not much divide public opinion, but the first phase of the papacy of Benedict XVI has seen at times far tougher confrontations over some positions of the Church. Doubts on the direction of the theological and political line of the Church are yet to be resolved: Alberto Melloni states in his chapter that it will take some time to understand the meaning and the consequences of the Church's positions for a now very composite and divided Catholic world. However, one cannot fail to note that the Italian Bishops' Conference (CEI) showed this year that it intends to return to expressing, in a frank and timely fashion, a series of positions based on the traditional view of the individual and the family. This view achieved a symbolic victory in the referendum on artificial insemination, a non-decision made as a result of the non-vote of many citizens, which in reality leaves the legislative questions just as unresolved as it does the moral ones (see on this the chapter by Chiara 
Martini). The revival of traditionalist Catholic positions is supported by the politically influential interventions of the UDC (but also Francesco Storace and a large portion of AN) and by a combative faction of Italian-style "theo-cons," who backed an investigation of the results of the emblematic law no. 194/1978 on abortion. Inevitably, tensions on these issues also provoke the re-emergence of secularism. The Radical-Socialist alliance, which came together precisely to defend the secular state, is in the end the only new formation on the political scene in 2005 , but it probably generates more problems than potential votes for the center-left coalition.

The sharpened debates on religious morality and scientific ethics also constitute a possible sign of a rift between civil and political society. We know from polls ${ }^{14}$ that religious issues are not a source of deep divisions in public opinion: 80 percent of Italians accept the role of the Church, and the majority do not reject the crucifix or religious education in school. But the actual positions of this majority on issues of religious freedom and tolerance are perhaps more flexible than those of the politicians. In the parties, Catholic conservatism is prevalent in the centerright alliance, while the leadership of the opposing coalition, in spite of its secular tendencies, often finds itself "seeking out" the ecclesiastical hierarchy, even if it does so in a variety of ways. It is probably no accident that 2005 was the year in which the secretary of the Left Democrats, Piero Fassino, felt the need to declare his religious faith publicly. ${ }^{15}$

\section{Prospects: A Need for Social Learning and Social Awareness}

While it may be almost too easy to catalogue 2005 as another stage in a permanent (or perhaps insubstantial?) transformation of the political system, it is also worthwhile to highlight those elements that may, instead, signal a change in the medium term for Italian politics. Naturally, there are two ways of viewing any type of change. On the one hand, these elements could be considered signs of a new order-more or less welcome, according to one's opinion-that breaks out of the cyclical nature of events and stimulates real growth in certain institutions and policies. On the other hand, we could point to the failure of some impulses toward change and then to a series of negative developments and risks of institutional deterioration, due to political stagnation and the persistence of unresolved structural problems.

Among the first set of elements we must include the conclusion of the long-running legislative itineraries of some measures (including devolution) and the consolidation of a series of rules and "sub-systems" 
in local politics, which by now are able to ensure a notable level of performance from these institutions. We are not, that is, at the year zero of the second (or third) ${ }^{16}$ Republic, if we look at the possibilities that are still open for finally constructing an effective political system. However, the risks of stagnation are many and obvious. The rift we noted in the course of the year between society and the political world is a serious problem for Italian democracy. In particular, the risk caused by the blindness of a political class preoccupied with the balance of power within the coalitions, and increasingly less able to measure the long-term effects of its policies on the "policy-takers," remains high.

Ultimately, the parallel between 2005 and 2000, with which we opened this introduction, can presage a kind of settling of the bipolar political system into a sequence of brief legislative cycles. But this does not eliminate the many factors of instability, starting with the reappearance of an embarrassing divergence between politics and public opinion. On the right, the primacy of Silvio Berlusconi is beginning to wane and the problem of choosing his successor is already coming up, with all the resulting threats to the cohesion of the Casa delle Libertà. On the left, the road toward the Democratic Party seems quite rocky, as is shown by the conflicts between Prodi and the leadership of the parties over the Ulivo's electoral lists for 2006.

Cementing support within the two fronts has sometimes seemed more difficult than it was 10 years ago. This is partly due to the complex composition of the two electoral camps, but also to an inability to stimulate the adoption of potential new "identity" values. The repeated efforts of the premier to return to anti-communism as the ideological cement for the moderate bloc are bound to encounter real limits, while free-market economics has difficulty taking root in a country like Italy, except as an expression of irritation at state supervision and the red tape of regulations or taxation. On the left, on the other hand, there is no longer the climate of national emergency or the external constraint of the Maastricht Treaty that had given momentum and unity to the Prodi government and facilitated its relations with its social partners. Mere opposition to Berlusconi has served as a unifying factor in recent years, but it is certainly not a sufficient one. The primaries have shown, however, that a "base" activated to legitimate the leaders directly can be more unified than the elite itself and can dissociate itself from the logic of competition and force the heads of the parties to patch up their differences.

Another element of potential instability is the dramatic reappearance of the issue of public morality, which came to the top of the political agenda first and foremost in the saga of the bank takeovers. It revealed not only the "amoral familism" (to cite Messori) of some high 
office-holders, but also the involvement of some representatives of the majority in the affair and, on the part of some opposition leaders, at the very least a lack of awareness of the rules of the market (a fact Berlusconi would exploit for electoral purposes at the beginning of the new year). The reform laws in the field of justice, which were perhaps aimed at helping some accused politicians get off more lightly in their trials, have increased the sense of unease among the public.

If the two coalitions were to continue to prove so fragile and unmanageable, the temptation of a centrist solution, perhaps in the shape of an "institutional" government, could emerge once again. Its policy would probably be inspired by "common sense" and technocratic expertise, but it would mean the inevitable eclipse of the prospect of a decisive transformation of the political system. The fact that 2005 avoided detours in this direction must therefore be considered a half-victory. But it is also difficult, writing on the eve of an important round of legislative elections, to say how and to what extent Italian politics can and should still accomplish such a transformation. It is therefore apparent that, leaving aside party coalitions and electoral outcomes, the first desideratum is a shift toward deeper kinds of change in public policy—to social learning that can finally create a solid legacy of understanding, information, and policy tools for the decision-makers of tomorrow. The second objective that the political and social elites should set for themselves is to regain a sense of public morality, which has been shaken by episodes like those involving the Bank of Italy and the everyday (and often offensive) language of politics. In this respect, the final year of the 14th Legislature has seen, if not a return to the dark period of Tangentopoli, at the very least a series of missed opportunities.

- Translated by Laura Kopp

\section{Notes}

We wish to thank the participants in the Italian Politics/Politica in Italia workshop in Bologna on 12 November 2005, and in particular those who at that time and later on discussed the first drafts of each chapter: Mario Caciagli, Aldo Di Virgilio, Pietro Manzini, Erik Jones, Piergiorgio Corbetta, Gilberto Capano, and Guido Legnante. Our collaboration on this project was also made possible by two periods of study abroad: Grant Amyot was a CIRCaP Visiting Fellow in Siena, and Luca Verzichelli was a guest of the European Studies Centre at St Antony's College, Oxford. We wish to thank the directors of the two centers, Maurizio Cotta and Timothy Garton Ash, respectively, for their hospitality. 
1. See S. Vassallo, "The Constitutional Reforms of the Center-Right," in Italian Politics: Quo Vadis? ed. C. Guarnieri and J. L. Newell (New York and Oxford: Berghahn Books, 2005), 117-135.

2. See M. Caciagli and A. Zuckerman, "Introduction: The Year before the Elections," in Italian Politics: Emerging Themes and Institutional Responses, ed. M. Caciagli and A. Zuckerman (New York and Oxford: Berghahn Books, 2001), 25-36.

3. R. D'Alimonte, Il Sole-24 Ore, 27 October 2005. This forecast was borne out in the subsequent election of April 2006, in which neither coalition obtained a clear majority in the Senate. As a result, the new government had to rely on the votes of the seven senators-for-life (translator's note).

4. This law regulates television advertising during campaigns, reducing somewhat the advantage Berlusconi derives from the ownership of the three largest private channels (translator's note).

5. Agreement was reached during the programmatic seminar held at the beginning of December: a center-left government would draw up a schedule for withdrawing Italian troops, in conjunction with the Iraqi government. This understanding did not fully satisfy any of the members of the coalition; some minor members were not even present at the seminar.

6. C. Guarnieri and J. L. Newell, "Introduction: 2004-a Year 'On Hold," in Italian Politics: Quo Vadis? ed. C. Guarnieri and J. L. Newell (New York and Oxford: Berghahn Books, 2005), 41.

7. OECD, Economic Surveys, no. 7 (November 2005).

8. Alleanza Nazionale was not able to obtain a cut in social insurance contributions for agriculture, which would have favored its electoral base in the South, but it did instigate the tax on producers of pornographic material. The Northern League also had to accept both the tax amnesty for the years 2003-4 and the use of the funds destined to top up firms' retirement bonus funds to reduce the deficit, pending the implementation of the reform of the retirement bonus (TFR) system.

9. S. Intravaia, La Repubblica, 5 January 2006.

10. Particularly intensive use of this tool was made in the final part of 2005, with repeated votes of confidence forced by the government on various provisions, including the bill on the career structure of university professors, the decree law that accompanied the budgetary maneuver, the "maxi-amendment" to the budget bill itself, and the bill on savings. In all, the year saw fully 15 bills passed in 2005 (and 42 in the entire course of the legislature) after recourse to votes of confidence. This is the highest average since 1948.

11. I. Diamanti, ed., "Italia 2005: Sì, svoltare. Ma dove andare?” Il Venerdì di Repubblica, no. 926, 16 December 2005, 29-37.

12. According to the 2006 Eurispes report (R. Amato, La Repubblica, 27 January 2006).

13. Note in addition that the participation in the demonstration of representatives of the Green Party, and the fact that the city secretary of Communist Refoundation was injured, illustrate the openness of some political groups, which also form part of the coalition supporting the mayor, to the immigrants' concerns.

14. Diamanti, "Italia 2005."

15. F. Ceccarelli, La Repubblica, 27 September 2005.

16. The expression was coined by Mauro Calise, who, even if simply as a provocation, proposes a third model after the "partitocracy" of the past and the "post-partitocratic transition" of the last decade. See M. Calise, La terza repubblica: Partiti contro presidenti (Rome-Bari: Laterza, 2006). 